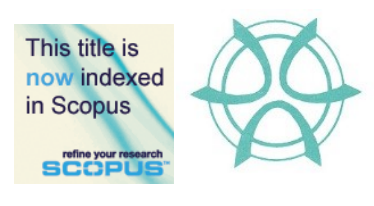

\title{
A GENERIC PROCESS OF DOCUMENTATION AND DATA MANAGEMENT FOR HISTORICAL MALAY ARCHITECTURE USING BIM
}

\section{Muhammad Hadi Mustafa ${ }^{1}$, Maisarah $\mathrm{Ali}^{2}$ Khairusy Syakirin HasYun Hashim $^{3}$ \& Mohamad Saifulnizam Mohd Suhaimi ${ }^{4}$}

${ }^{1,3,4}$ Kuliyyah of Architecture and Environmental Design, INTERNATIONAL ISLAMIC UNIVERSITY MALAYSIA

\author{
${ }^{2}$ Kuliyyah of Engineering \\ INTERNATIONAL ISLAMIC UNIVERSITY MALAYSIA
}

\begin{abstract}
Historical Malay Building Information Modelling (HMBIM) is a prototype library of historical Malay BIM objects, which are developed based on historical study on the architecture of Malay heritage. The objective of this paper is to outline a generic process of documentation and data management (data collection, modelling and retrieval using BIM), specific for the preservation and conservation effort of Malay architecture. This research employs multiple case studies technique and the process begins with the collection of data using multiple reliable sources namely archival reports, measured drawings and scan-to-BIM. HMBIM is enriched using reverse engineering approach where the information about building components are semantically identified according to Malay architecture characteristics and enriched into data coding system. Since there is no standard approach for conservators in the work of conservation, assembly and disassembly of Malay buildings in Malaysia, HMBIM is anticipated to be able to suggest 'standard' for the work. The main output for this paper is the creation of framework in demonstrating the processes involved.
\end{abstract}

Keywords: BIM, Malay architecture, data management, BIM library, HBIM

${ }^{1}$ Ph.D. candidate at International Islamic University Malaysia. Email: hadimustafaphd@gmail.com 
Muhammad Hadi Mustafa, Maisarah Ali, Khairusy Has-Yun Hashim, \& Saifulnizam Suhaimi,

A Generic Process of Documentation and Data Management for Historical Malay Architecture using BIM

\section{INTRODUCTION}

This research aims to highlight the processes in studying the documentation of historical Malay architecture using Building Information Modelling (BIM) technology. Since there is no standard approach for conservators in the work of conservation, assemblies and disassembly of Malay buildings in Malaysia (Ab Rashid \& Daud, 2014), this paper is anticipated to suggest 'standard' for the work. There are differences in current practices in the documentation process. In contrast, previously, information was gathered and stored within thick documents and was difficult to access, but with BIM (which is empowered by improvement in technology), information can be managed in a more efficient way using computers and databases.

Although the concept of BIM was introduced in the 1970s by Charles Eastman, the adoption of the approach is still slow and low in a country such as Malaysia (CIDB, 2017; Zakaria, Nasly, Haron, Marshall-Ponting, \& Abdul Hamid, 2014). BIM enhanced by the existence of an abundance of data; however, these data need to be managed and turned into 'smart-data'; to facilitate the use of BIM effectively. This research considers two underlying issues currently exist; i) Malay architecture is diminishing in developing South East Asia countries such as Malaysia and ii) slow adoption of BIM approach in Malaysia despite BIM is now considered as the standard of doing works in AEC industry worldwide.

The attempt on this issue has never been widely addressed before, particularly in Malaysia; where the tangible historical Malay buildings components are turned into digital data using BIM technology and later, translated into a cultural BIM database. Through the study on historical Malay architecture using multiple case studies, employing multiple data collection techniques such as 'scan-to-BIM', measured drawings and archival reports, the processes of collecting data are documented as a framework model where the output is anticipated to act as a guideline in preserving cultural heritage using BIM.

\section{BIM Library as Data Documentation}

A BIM library can be defined as 'a digital database of semantically rich BIM objects that are contributed by open access sources, unified to the specific parameter format, and integrated into a well-defined library structure" (Lu, Chen, Wang, \& Xue, 2017). Previous researches (Dore \& Murphy, 2017; De Luca, 2013; Ali, Ismail, Has-yun, Suhaimi, \& Mustafa, 2018) have reported that the usage of BIM for historical buildings have many advantages. However, these advantages can only be achieved if the model and its database are successfully realised (Ab Rashid \& Daud, 2014). Oreni et al., (2014) and other BIM practitioners such as Autodesk and National Building Specifications have suggested that the realisation of the model and its database can be expounded 
PLANNING MALAYSIA

Journal of the Malaysia Institute of Planners (2020)

through the creation of BIM library, with an easy and straightforward retrieval system.

Moreira A., Quattrini R., Maggiolo G., \& Mammoli R., (2018) and Lu et al., (2017) observed that designers would drag various objects from a library and add extra semantics such as materials when practicing BIM. There are lots of BIM objects libraries available nowadays. Without the readily available welldefined objects, designers have to draw all the objects from scratch and form them into a BIM (Lu et al., 2017). This would be costly and burdensome for them. The abundance of BIM objects in the libraries available worldwide have indicated that there are lots of data available for BIM practices, despite it is observed that most of the objects available focus on contemporary designs instead of historic (cultural) design. However, regardless of the available amount of data, the management and usage of the data carry a more substantial concern.

BIM libraries can be advantageous if it is used in a 'smart' way, but most of the libraries are generic since currently, there is no standardization in the way of handling them. If appropriately used, BIM libraries will give users the leverage to optimise their spending and establish higher profitability in conducting their activities. Since there are various attempts by various parties worldwide, the standard format in building information exchange must be made standardised. This is to ensure better readability of data and increased data usefulness. In Malaysia, especially in the context of utilizing BIM for cultural heritage preservation, little effort has been carried out (Zakaria et al., 2014). Confusion on data available is among the problem. In conservation work, due to uniqueness of Malay architecture which can be disassembled, where during re-assemblement of components, conservator is exposed to the risk of mistaking components' location. This is because currently, there is no specific format on the historical building information exchange. However, in practicing BIM for new buildings, there are some guidelines outlined by National Building Specifications (NBS), highlighting the usage of similar formats such as Uniclass and Omniclass, which can be referred.

\section{METHODOLOGY}

This research employs multiple case studies method which uses three different data collection techniques, namely i) archival reports, ii) measured drawings and iii) 'scan-to-BIM'. Historic Malay palaces were selected as this research case study because the 'istana' (palace) is believed to be able to provide more data as compared to other Malay buildings such as the traditional Malay houses due to its size and complexities (Mustafa, Ali, Ismail, Hashim, \& Suhaimi, 2019).

The archival reports are among the method of documentation in the early days. Documentation for cultural heritage buildings is driven by the information and sources used to build them and the real value proposition of it to analyse data (Baik, Boehm, \& Robson, 2013). These conventional methods of 
Muhammad Hadi Mustafa, Maisarah Ali, Khairusy Has-Yun Hashim, \& Saifulnizam Suhaimi,

A Generic Process of Documentation and Data Management for Historical Malay Architecture using BIM

architectural documentation on existing building are done manually by a measured drawing. Measured drawings are carried out to retrieve information such as dimension and the form of a building in the architectural study (Harun, 2011). This technique used measuring tools; a measuring tape, adjustable set square rulers, ladder, graph papers and pens, conducted in a large group of 10-20 people. The measurement recorded will be drawn on the butter paper and redrawn for documentation. On the other hand, measured Computer Aided Drawings (CAD) is a more advance source of documentation compared to paper documentation. The production is still via measurement on-site, but instead, the data was recorded into hardcopies, it was re-drawn using newer technology such as computers, thus minimizing errors as compared to hand-written drawings.

Lastly, the third approach which utilizes laser scanning technology is deemed to be known as the most advanced method of documentation available nowadays in the industry. Terrestrial Laser Scanner (TLS) is an automatic tool used to measure the 3D coordinates based on the scanned object in X, Y, and Zaxes. An object's data can be collected and are based on the scanned surface which reflects an encoded angular orientation in the form of point clouds, thus making the object collected into 3D data (Amparo, Pozuelo, Marimón, \& Mesa, 2012). The usage of TLS for BIM is also known as Scan-to BIM approach.

\section{ANALYSIS FOR THE DEVELOPMENT OF FRAMEWORK}

In order to develop a BIM- process framework for Malay historical architecture documentation, three case studies exploring three different documentation approaches for BIM are explored. From the collected data, the buildings were modelled into BIM using Autodesk Revit.

BIM is an emerging trend in the architectural documentation scenario; as it is a representation of physical and functional features of facilities in digital form, BIM is an approach in which different players act by sharing data through digital models in a coordinated process. As the adoption of BIM grows, designers and contractors will require model-based BIM-ready information (Baik et al., 2013) to integrate the data into their building model. Thus, there is an urgent need to get fast and efficient ways to shift from raw data to a complete and informationenriched building components model. At the same time, also in the domain of heritage building, the ability to manipulate structured 3D models has become an increasing need to handle conservation, restoration, modification and to support their management (Hichri, Stefani, De Luca, \& Veron, 2013). Thus, it is essential to ensure the collected data is classified and structured in an agreed way so that different stakeholders can easily find what they need and are able to understand the data. Figure 1 shows the process for data collection, and digitalization of BIM using the multiple approaches and Table 1 shows the result on the comparison of data collection technique used in this research. 
PLANNING MALAYSIA

Journal of the Malaysia Institute of Planners (2020)

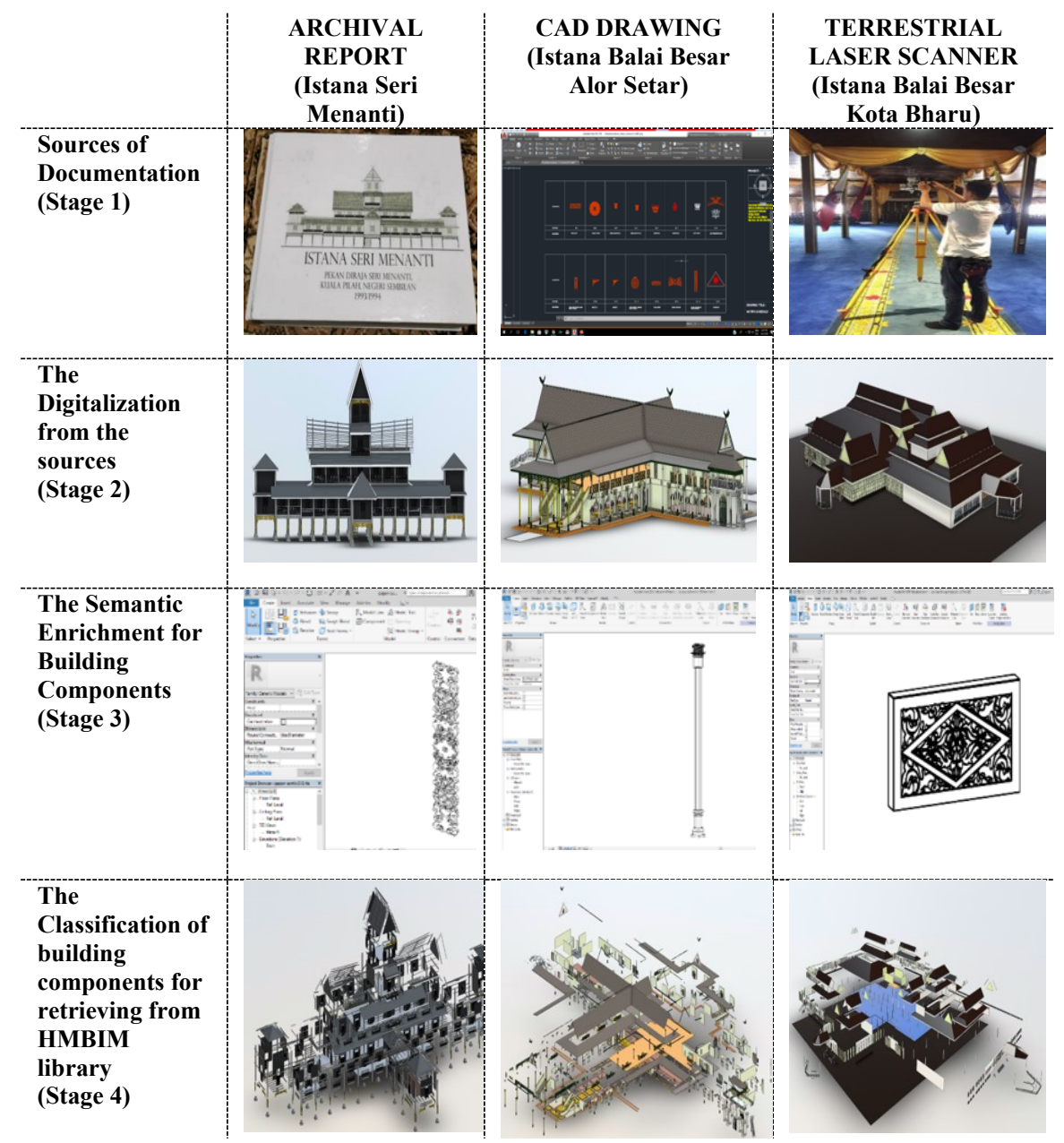

Figure 1: The process and result for BIM digitalization using multiple approaches Source: Authors (2020)

Table 1: The comparison of multiple data collection techniques for HMBIM

\begin{tabular}{llll}
\hline $\begin{array}{l}\text { Approach / } \\
\text { Observation }\end{array}$ & $\begin{array}{l}\text { Archival } \\
\text { Reports }\end{array}$ & $\begin{array}{l}\text { Measured } \\
\text { CAD }\end{array}$ & $\begin{array}{l}\text { Terrestrial } \\
\text { Laser Scanner }\end{array}$ \\
\hline $\begin{array}{l}\text { Dimension } \\
\text { (Height, width, length) }\end{array}$ & $\begin{array}{l}\text { Relatively } \\
\text { accurate }\end{array}$ & $\begin{array}{l}\text { Relatively } \\
\text { accurate }\end{array}$ & Accurate \\
\hline Visibility & Low & $\begin{array}{l}\text { High, depending on } \\
\text { availability of elevations }\end{array}$ & Very high \\
\hline Detailing & As photographed & As drawn & High \\
\hline Data Size & Small & Big & Very big \\
\hline $\begin{array}{l}\text { Availability of } \\
\text { Intangible information }\end{array}$ & Yes & No & No \\
\hline & & & Source: Authors (2020)
\end{tabular}


Muhammad Hadi Mustafa, Maisarah Ali, Khairusy Has-Yun Hashim, \& Saifulnizam Suhaimi,

A Generic Process of Documentation and Data Management for Historical Malay Architecture using BIM

The digitalization took some challenges such as on the tracing for intricate geometric classical designs. As cultural buildings have lots of ornamentation, the process of modelling took some time. Some problem also was faced, such as the limitation of the BIM software to draw 'sharp lines' where design with some very curvy angle was concerned. The lines were unable to close the loop if the spline is continuously drawn. This has made the work of remodelling intricate designs such as ornamentation to be tedious and troublesome. Ornamentation design was traced within Revit, and this limitation was overcome by non-continuous tracing technique. The result is similar to a continuous line drawing, but it does consume more time compared to continuous line tracing. The work can be troublesome when the software only notifies the modeller after continuous line technique was used, to know that the form cannot take place using the tracing technique. This will make the modeller remodel them from scratch again. Another consideration is better if Revit has a loft feature such as in Autodesk Solidworks. A loft feature is an important tool for surface modelling. The loft feature creates a shape by making transitions between multiple profiles and guide curves (Barazzetti, Banfi, Brumana, \& Previtali, 2015). However, Autodesk is most likely will not do so since Revit is not intended to be the do-all type of software. It does have a limitation so that other software from Autodesk can be utilized as well. Another Revit's limitation is that it was never designed to be a rendering platform and nor should it be.

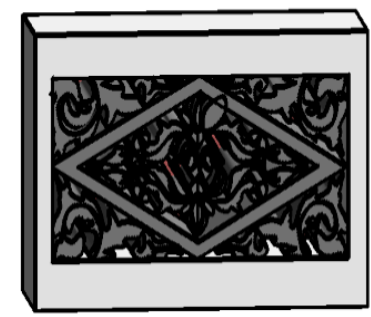

Figure 2: The BIM production of ornamented vent Source: Authors (2020)

In digitalizing historical Malay architecture, some of the ornamentation design do have voids such as vent found in Istana Balai Besar Kota Bharu (Figure 2). To model this design, it is vital to identify the basic shape as the first step. The symmetrical parts of the design must be identified. This is to ensure no redundancy in modelling the same shape within a design because in the software, 'mirroring' is possible. An example is like the one found in the intricate ornamentation of Istana Seri Menanti (Figure 3). Failure to identify the basic grammar shape of the design will lead to a much longer modelling work. The shape grammar of architectural work was extensively discussed since the $15^{\text {th }}$ century and were documented in the Four Books of Architecture (Palladio, 1570). 


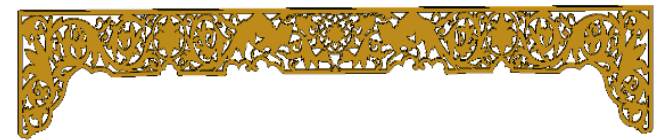

Figure 3: Example of complex ornamentation in Istana Seri Menanti Source: Authors (2020)

One of the most essential features of the BIM model is the ability to insert attributes as embedded information within the model. After the digitalization process, information enrichment needs to be conducted. Since this research deals with historical buildings with more than 100 years of history, the process of gathering information about the building can be challenging. Some information is limited and may be difficult to be retrieved. However, with the data collection approaches conducted, it can be seen that some information such as the buildings' dimension, total floor areas and quantities of elements inside the building can be recorded. Apart from that, enrichment from the aspect of semantic can also be carried out. Semantic enrichment is deemed necessary since the design of the components in the historical buildings may represent heritage significance for a culture. This is what is being adopted as the main argument of this process: the digitalization is an approach of preservation and documenting traditions that were in use when the buildings were made and subsequently, maintained throughout its life as part of the effort to ensure the authenticity of cultural properties. This is comparable to Riegl's claim (1903) that any historical building's authenticity and genuineness are related to the substance acquired through its history.

In this research, the process of semantic enrichment did face some challenges such as unavailability of data and confusion on the terminology used as some sources were recorded in classical language, which needs an explanation from linguists and historians. For example, the usage of a variant of Tiang Menungkat Pisang Sesikat (structural column) that are found in the case study of Istana Balai Besar Alor Setar. The usage of semantic for 'Pisang Sesikat' might carry various meaning to some practitioner. Phenomenologically analysed, it might have gotten its name from a banana (Pisang) tree, which is generally found in the yard of a building. However, surprisingly, the term is unique when this research re-discovered that the 'Pisang Sesikat' is referring to the front entrance roof (Nasir, 1985). The name Tiang Menungkat Pisang Sesikat is actually referring to a specific column that, generally found at the front zone of a building, which holds the front entrance roof. A "Pisang Sesikat" is a small extension made on one side of the building which incorporated a lean-to roof (Endut, 1993). This richness of this culturally unique semantic can be inserted into the BIM model as attributes and also information to be passed on to future generation. As technology grows, the approach of preserving works also need to be parallel, so that these efforts will be future-proof. 
Muhammad Hadi Mustafa, Maisarah Ali, Khairusy Has-Yun Hashim, \& Saifulnizam Suhaimi,

A Generic Process of Documentation and Data Management for Historical Malay Architecture using BIM

After the data enrichment stage, the work should be able to be distributed so that the work can be utilized and remain relevant. The practitioners should be able to retrieve the work for their undertaking and to some extent, challenge the information embedded inside the model, as to encourage development. The next stage requires the data to be able to be 'smartly-identified' for easy and functional retrieval. This is the most crucial stage in establishing the work.

The concept of BIM documentation is to allow convenient and informative retrieval approach, where specification and BIM object are sourced from the same location and driven by the same database. The concept of a specification is to provide documentation of specified elements of a project. This can be generated through the interpretation of building ontology and taxonomy theory as had been previously suggested by Lee, Min, Lee, Kim, \& Kim (2008) and Mustafa et al., (2019). Their suggestions draw upon what is chosen to clarify why it is used. Abidin (1981) and Mustafa et al., (2019) also highlighted the importance of comprehension of the buildings spaces and components as the specification should be designed through the creation of a preformatted guide design. Figure 4 demonstrates a suggested retrieval specification which is based on the study of historical Malay architecture and buildings. At this point, from the exercise, researchers were able to come out with a model for the works discussed. The final production on the framework is shown in Figure 5.

\begin{tabular}{|c|c|c|c|c|c|c|c|}
\hline Building & Floor & Trade & Zone & Area & Element & Material & Variant \\
\hline $\begin{array}{l}\text { Balai Besar } \\
\text { Alor Setar }\end{array}$ & $\begin{array}{l}\text { Ground } \\
\text { Floor }\end{array}$ & Structural & $\begin{array}{l}\text { Front } \\
\text { Zone }\end{array}$ & Serambi & Column & Concrete & $\begin{array}{l}\text { Pisang } \\
\text { Sesikat }\end{array}$ \\
\hline $\begin{array}{l}\text { Balai Besar } \\
\text { Kota Bharu }\end{array}$ & $\begin{array}{l}\text { First } \\
\text { Floor }\end{array}$ & $\begin{array}{l}\text { Non } \\
\text { Structural }\end{array}$ & $\begin{array}{l}\text { Main } \\
\text { Zone }\end{array}$ & $\begin{array}{l}\text { Ruang } \\
\text { Tamu }\end{array}$ & Wall & Timber & $\begin{array}{l}\text { Janda } \\
\text { Berhias }\end{array}$ \\
\hline $\begin{array}{l}\text { Istana Seri } \\
\text { Menanti }\end{array}$ & & Decoration & $\begin{array}{l}\text { Rear } \\
\text { Zone } \\
\text { Kitchen } \\
\text { Zone }\end{array}$ & $\begin{array}{l}\text { Pelantar } \\
\text { Dapur }\end{array}$ & Window & Glass & \\
\hline
\end{tabular}

Building/Floor/Trade/Zone/Area/Element/Material/Variant BBAS/ GF/ Deco/ Front/ Serambi/ Col/ Con/ Pisang Sesikat

Figure 4: Retrieval specification for HMBIM data Source: Authors (2020) 


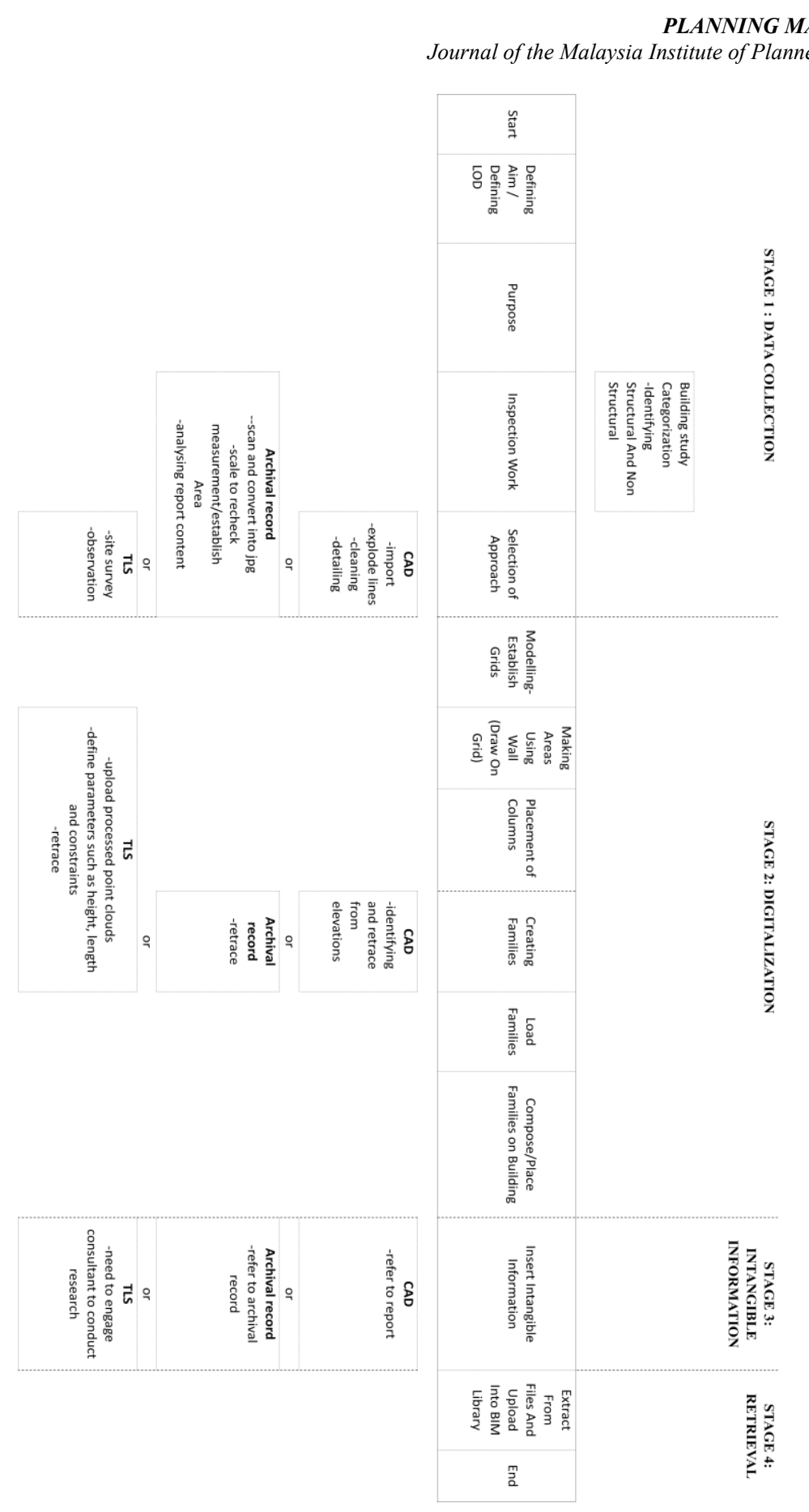

Figure 5: The Framework on Documentation and Data Management for HMBIM Source: Authors (2020) 
Muhammad Hadi Mustafa, Maisarah Ali, Khairusy Has-Yun Hashim, \& Saifulnizam Suhaimi,

A Generic Process of Documentation and Data Management for Historical Malay Architecture using BIM

This research undergoes the processes in utilizing BIM as a tool for documenting historical Malay buildings. From this, it can be outlined that within a generic process of documentation and data management (data collection, modelling and retrieval using BIM, there are 4 phases within the framework. In embracing Industrial Revolution 4.0, the utilization of tools such as BIM is encouraged by the government of Malaysia when they mandated that starting 2020, construction projects must be BIM-operated. Therefore, it is essential to create a system that is universal and expandable that reflects the character of Malay building, to ensure the continued relevance of the effort. Multiple approaches of existing data collection are utilized and made as a standard in documenting and managing data related to historic buildings, especially in terms of their intangible information such as semantic data since historic buildings are rich with cultural names and terms. The framework is anticipated to act as the basis for further exploration in this area.

\section{CONCLUSION}

The main output for this paper is the creation of framework in demonstrating the processes of documentation and data management (data collection, modelling and retrieval using BIM). HMBIM particularly is addressing the issue which is not widely addressed before in Malaysia, where the tangible historical Malay buildings components are turned into digital data using BIM technology and later, translated into a cultural BIM database. Through the study on historical Malay architecture using multiple case studies, HMBIM is anticipated to provide access to industry players to consider components with Malay identity in their design. By having this kind of effort, it will increase the productivity and creativity of the industry, other than encouraging the players to be more competitive using output from a scientific research. Apart from that, by utilizing BIM approach, the government's aspiration to contribute to the world's sustainable goal development also can be addressed.

\section{ACKNOWLEDGEMENTS}

This research was supported by a grant (TRGS/1/2016/UIAM/01/5/3) from the Ministry of Higher Education Malaysia (MOHE). This research is also supported by Kuliyyah of Architecture and Environmental Design (KAED) and Kuliyyah of Engineering of International Islamic University Malaysia.

\section{REFERENCES}

Abidin, W.B.b.W. (1981). The Malay House: Rationale and Change (Master Thesis). M.I.T., Massachusetts. Cambridge.

Ab Rashid, N. S., \& Daud, N. I. M. K. (2014). The Suitability of Adaptive Reuse Practices on Historic Residential Buildings to National Memorials. Journal of Design and Built Environment, 14(June), 1-13.

Ali, M., Ismail, K. M., Has-yun, K. S., Suhaimi, S., \& Mustafa, M. H. (2018). Heritage 
Building Preservation Through Building Information Modelling: Reviving Cultural Values Through Level of Development Exploration. Journal of the Malaysian Institute of Planners, 16(2), 62-72.

Amparo, N. A., Pozuelo, F. B., Marimón, J. R., \& Mesa, A. de. (2012). Generation of virtual models of cultural heritage. Journal of Cultural Heritage, 13(1), 103-106. https://doi.org/10.1016/j.culher.2011.06.004

Baik, A., Boehm, J., \& Robson, S. (2013). Jeddah historical building information modeling " JHBIM " Old Jeddah - Saudi Arabia Jeddah Historical Building Information Modeling " JHBIM " Old Jeddah - SAUDI ARABIA. International Archives of the Photogrammetry, Remote Sensing and Spatial Information Sciences, XL(5/W2), 73-78. https://doi.org/10.5194/isprsarchives-XL-5-W2-732013

Barazzetti, L., Banfi, F., Brumana, R., \& Previtali, M. (2015). Creation of Parametric BIM Objects from Point Clouds Using Nurbs. Photogrammetric Record, 30(152), 339-362. https://doi.org/10.1111/phor.12122

CIDB. (2017). Malaysia Building Information Modelling Report 2016.

De Luca, L. (2013). 3D Modelling and Semantic Enrichment in Cultural Heritage. In Photogrammetric Week 2013 (pp. 323-333).

Dore, C., \& Murphy, M. (2017). Current State of The Art Historic Building Information Modelling. In The International Archives of the Photogrammetry, Remote Sensing and Spatial Information Sciences (Vol. XLII-2/W5, pp. 185-192). https://doi.org/10.5194/isprs-archives-XLII-2-W5-185-2017

Endut E. (1993), Traditional Malaysian Built Forms: A Study Of The Origins, Main Building Types, Development Of Building Forms, Design Principles And The Application Of Traditional Concepts In Modern Buildings, thesis submitted to university of Sheffield (November 1993)

Harun, S. N. (2011). Procedia Engineering Heritage Building Conservation in Malaysia : Experience and Challenges. Procedia Engineering, 20, 41-53. https://doi.org/10.1016/j.proeng.2011.11.137

Hichri, N., Stefani, C., De Luca, L., \& Veron, P. (2013). Review of the "As-Built Bim" Approaches. ISPRS - International Archives of the Photogrammetry, Remote Sensing and Spatial Information Sciences, XL-5/W1(February), 107-112. https://doi.org/10.5194/isprsarchives-xl-5-w1-107-2013

Lee, J., Min, K., Lee, Y., Kim, J., \& Kim, J. (2008). Building Ontology to Implement the BIM ( Building Information Modeling ) Focused on Pre-Design Stage Building Ontology to Implement The BIM ( Building Information Modeling ) Focused on Pre-Design Stage. In The 25th International Symposium on Automation and Robotics in Construction (pp. 350-354). https://doi.org/10.22260/ISARC2008/0053

Lu, W., Chen, K., Wang, J., \& Xue, F. (2017). Developing an Open Access BIM Objects Library: A Hong Kong Study. In Proceedings of the Joint Conference on Computing in Construction (pp. 407-414). https://doi.org/10.24928/JC32017/0254

Moreira A., Quattrini R., Maggiolo G., \& Mammoli R. (2018). HBIM Methodology As a Bridge Between Italy and Argentina. The International Archives of the Photogrammetry, Remote Sensing and Spatial Information Sciences, XLII(2), 
Muhammad Hadi Mustafa, Maisarah Ali, Khairusy Has-Yun Hashim, \& Saifulnizam Suhaimi,

A Generic Process of Documentation and Data Management for Historical Malay Architecture using BIM

$715-722$

Mustafa, M. H., Ali, M., Ismail, K. M., Hashim, K. S., \& Suhaimi, M. S. (2019). Spatial Analysis on Malay Buildings For Categorization of Malay Historic BIM Library. International Transaction Journal of Engineering, Management, \& Applied Sciences \& Technologies (Vol. 11). https://doi.org/10.14456/ITJEMAST.2019.22

Nasir A. H. (1985), Introduction to Traditional Malay Houses in Peninsular Malaysia, Kuala Lumpur: Darul Fikir Press

Oreni, D., Brumana, R., Torre, S. Della, Banfi, F., Barazzetti, L., \& Previtali, M. (2014). Survey turned into HBIM : The restoration and the work involved concerning the Basilica di Collemaggio after the earthquake ( L' Aquila ) Survey Turned Into Hbim: The Restoration And The Work Involved Concerning The Basilica Di Collemaggio After The Year. ISPRS Annals of the Photogrammetry, Remote Sensing and Spatial Information Sciences, 2(5), 267-273. https://doi.org/10.5194/isprsannals-II-5-267-2014

Palladio A., (1570). I Quattro Libri dell'Architettura. Venezia; (1965). The Four Books on Architecture, translation by Isaac Ware 1738, Dover Publications, New York

Riegl, A. (1903) 'The Modern Cult of Monuments: Its Character and Its Origin', Oppositions, 25/Fall 1982: p. 21- 51, 1982

Zakaria, Z., Nasly, M. A., Haron, A. T., Marshall-Ponting, A., \& Abdul Hamid, Z. (2014). Exploring the Barriers and Driving Factors in Implementing Building Information Modelling ( BIM ) in the Malaysian Construction Industry : A Preliminary Study. The Institution of Engineers, Malaysia, 75(1), 1-10.

Received: January 2020. Accepted: $1^{\text {st }}$ April 2020 